\title{
Determinants of Non-Farm Employment and Farm Production of Small Holder Farmers in Huambo District of Wolaita Zone, Ethiopia
}

\author{
Fetagn Gizachew*
}

\begin{abstract}
Non-farm employment provides an important potential source of income for many landless and near-landless households in Ethiopia. The study identified household level determinants of non-farm activity participation in Humbo District of Wolaita Zone, Ethiopia using cross-sectional data obtained from 118 randomly selected farmers in 2018 production year. To achieve this objective, a binary logit model was used to analyze the determinants of participation in non-farm activities. 14 Variables were included in the model of which 5 variables were found significant. Training on entrepreneurship \& input use were significant at $1 \%$, credit use \& cultivated land were significant at 5\% significance level and Age was significant at 10\% significance level. Policy implication of this study was that the rural development strategy should not only emphasis in increasing agricultural production but affiliated attention should be given in promoting non-farm activities in the rural areas, accessing training on nonagricultural sector will expand the household's choice of non-farm activities and the rural policy would do well to provide better access to credit for the rural people by motivating micro-finance institutions.
\end{abstract}

Keywords: Non-farm Employment, Logit Model, Humbo, Ethiopia.

DOI: $10.7176 / \mathrm{DCS} / 10-1-03$

Publication date: January $31^{\text {st }} 2020$

\section{INTRODUCTION}

\subsection{Background of the Study}

As government report (MoA, 2012) indicated that Ethiopia has been registering high economic growth (11\%) in the recent years, however, there was significant poverty and chronic food insecurity in the country. Most of these food insecure households were subsistence farmers and vulnerable to weather fluctuation and high population growth had contributed to decline to the farm size and environmental degradation stay a problem (Tekle and Berhanu, 2015).

According to MoA,(2012), nearly 55 percent of all smallholder farmers operate on less than one hectare of land due to smaller farm size and low return from farming activity, majority of rural households were exposed to food insecurity and chronic poverty.

These problems were coupled with those relating to land tenure, lack of inputs, inadequate and fragmented farm size, pricing, marketing and overall macro-policies of the country. The development of agriculture had to be seen not only as a sectorial problem but also as an inter-sectorial problem Tewdros Girma and Van dea Berg (2012).

Many researchers had noted the vital role of non-agricultural activities in bringing about rural progress. In Ethiopia, based on a large-scale household survey in high potential agricultural areas of the country Off-farm income in Ethiopia is relatively low compared to other countries and is significantly related to the agricultural sector. It is estimated that crop income makes up 71 percent of total household income. Wage income makes up 10 percent of total household income, which roughly equates to the income share that households derive from livestock and livestock products. Enterprise income accounts for 8 percent of household income. (EFPRI, 2016).

But most Ethiopians are rural dwellers and subsistence farmers, the poorest 40 percent tend to be even more likely to live in rural areas and engage in agriculture, where there is high vulnerability of returning to poverty, especially for rural livelihoods dependent on rain fed agriculture (WB, 2016).

As a result, promotion of non-farm employment as a policy had gained widespread support across a field of development agencies ranging from the World Bank to nongovernmental organizations, especially in countries facing repeated income and consumption shocks.

The study was conducted in Wolaita zone, Humbo District, which was located in the Southern Nations Nationalities and Peoples Regional State were characterized by a large number of non-farm activities.

\section{RESEARCH METHEDOLOGY}

\subsection{Description of Study Area}

Humbo is one of the districts of Woliata Soddo zone located along Abaya, $408 \mathrm{~km}$ away from Addis Ababa, 178 $\mathrm{km}$ from Hawassa and $18 \mathrm{~km}$ from the zone's town, Woliata Soddo. The altitude Ranges from 1100 to 2355 m.a.s.l. The district covers a total area of 86,646 hectares. The area is sub divided into two agro ecological zones: lowland (kola 70\%) with an altitude below 1500 m.a.s.l and midland (weinadega 30\%) with an altitude range of 1500-2355 m.a.s.1. Total population of the District is estimated as 86,509 out of which 172,487 are male $\& 8,598$ are female 


\section{(HDFEDO,2017).}

Different types of non-farm activities could be performed by farmers in rural areas. These activities and their dominance vary from place to place. In the study area, the predominant non-farm activities were petty trade, daily labor, formal non-farm employment, firewood and charcoal sale, food preparation and sale, handicraft, carpentry, transportation of produces by donkey cart(from and to the market/farm), red ash, coble stone \& sand extraction and sale, tailoring \& butchery activities were predominant in Humbo District (HDAO, 2017).

The numbers of households engaged in trade in Humbo District were very high. The dominant form of trade was livestock trade, grain trade, pajama pea trade and coffee trade, and sheep and goat trade. Most trade was retail trade with little or no wholesaling activity. As was evident, trade was based mainly on agricultural activity.

Handicraft was practiced in all Kebeles in Humbo District. It was, however, predominantly practiced. The predominant handicraft activity in this District was blacksmithing, (arata) making skin for siting purpose and weaving. Handicraft activities were inherited from family and in some cases are learned from friends and neighbors. In many cases handicraft activity becomes a family affair in which members of the family participate. In the study area, family members' participation was mainly in the form of providing support services. For example, it was observed that in the case of blacksmithing. The household head does the main job of smelting and production, children and wife keep the fire going, assist in supplying materials, etc.

Handicraft activity was done mainly during a slack period and hence it does not conflict with farm schedules of the farmers. Farmers engaged in these activities were comfortably placed in the society as the communities were favorably disposed towards these activities and farmers wish to continue with these activities.

\section{Data Types, Sources and Methods of Data Collection}

For this study, both primary and secondary data from different sources were used.

\section{Sampling Techniques \& Sample Size Determination}

Three stages random sampling procedure was used for the selection of sample household heads. In the first stage, Humbo District was selected purposively because it is one of the foods insecure, with large numbers of unemployment and non-farm practicing district. In the second stage, with the consultation of District experts, out of 41 kebeles of the district, 6 potential non-farm practicing kebeles were randomly selected.

In the last stage, from 2834 vegetable producers in Humbo district about 118 samples of household heads were randomly selected, using probability proportionality size following a simplified formula provided by (Yamane, 1967). Accordingly, the required sample size at $95 \%$ confidence level with degree of variability of $5 \%$ and level of precision equal to $9 \%$ are used to obtain a sample size required which represent a true population.

Assuming $e=9 \%$ precision level.

$\mathrm{n}=\frac{\mathrm{N}}{1+\mathrm{N}\left(\mathrm{e}^{2}\right)}$

$\mathrm{n}=\frac{2834}{1+2834\left(0.09^{2}\right)}=118$

Where $\mathrm{n}$ is the sample size, $\mathrm{N}$ is the population size (sampling frame) which is $2834 \mathrm{HHs}$, e is the level

of precession considered $e=9 \%$.

Methods of Data Analysis

\section{Descriptive statistics}

Descriptive statistics give a clear picture of the characteristics of farm and non-farm sample units. By applying descriptive statistics, one can describe, compare, and contrast different categories of sample unit (farm and nonform households) with respect to the desired characteristics.

\section{Logistic regression model}

Logistic regression model was used to identify the determinants of non-farm activities. In the studies on non-farm activities responses to the questions such as whether a household participates in non-farm activities could be "yes" or "no", a typical case of qualitative dichotomous variable. Ferder etal (1985) pointed out that the most commonly used qualitative response models are the logit model, which corresponds to a logistic distribution function, and the probit model.

These models specify a functional relation between the probability of participating in nonfarm activities and various explanatory variables. Hence, factors (independent variables) that affect farmers' participation in non-farm activities can be expressed both quantitatively and qualitatively. Both models have been used inter-changeably and give similar results. However, logit model is simpler in estimation than probity model (Aldrich and Nelson, 1984). Drawing upon Gujarati (2003) and Aldrich and Nelson (1984) the logit distribution function for the participation in non-farm activities is specified as:

$$
p_{i}=\frac{1}{1+e^{-z_{i}}} \ldots \ldots \ldots . . . .
$$


Where $p_{i}$ : is the probability of participating in non-farm activities.

$\mathrm{Z}_{\mathrm{i}}$ :is afunction of $\mathrm{n}$-explanatory variables $(\mathrm{x})$ and expected as :

$$
z_{i}=\beta_{0}+\beta_{1} \mathrm{X}_{i 1}+\beta_{2} \mathrm{X}_{i 2}+\ldots+\beta_{n} \mathrm{X}_{i n} \ldots(2)
$$

Where: $\beta_{0}$ is the intercept

$\mathrm{B}_{1}, \beta_{2} \ldots \beta_{\mathrm{n}}$ are coefficients of the equations in the model

The slop tells how the log-odd in favor of participating in non-farm activities as independent variable change.

$$
p_{i}=\frac{1}{1+e^{-\left(\beta_{0}+\beta_{1} X_{I}+\beta_{2} X_{2}+\ldots+\beta_{N} X_{N}\right)}} .
$$

This means that we cannot use the OLS procedure to estimate the parameters. But this problem is more apparent than real because this equation is intrinsically linear which can be shown as follows. If $\mathrm{p}_{\mathrm{i}}$ is the probability of participating in non-farm activities, then $\left(1-p_{i}\right)$ the probability of not participating in non-farm activity can be written as

$$
1-p_{i}=\frac{1}{1+e^{z_{i}}}
$$

Therefore, taking the ratio of the probability of participating to non-participation can be written as:

$$
\begin{aligned}
& \frac{p_{i}}{1-p_{i}}=\left[\frac{1+e^{z^{i}}}{1+e^{-z_{i}}}=e^{z_{i}} \ldots \ldots .\right] \ldots \ldots \ldots . . . . . \\
& \frac{p_{i}}{1-p_{i}}
\end{aligned}
$$

It is the ratio of the probability of that the farmer will participate in non-farm activities to the probability that he will not participate. Finally taking natural log of equation 5 we get:

$$
L_{i}=\ln \frac{p_{i}}{1-p_{i}}=z_{i}=\beta_{0}+\beta_{1} x_{i 1}+\beta_{2} x_{i 2}+\ldots+\beta_{n} x_{i n}
$$

Where $\mathrm{L}_{\mathrm{i}}$ is $\log$ of the odds ratio, which is linear not only in $\mathrm{x}$ but in also parameters. Thus, if the stochastic disturbance term $\left(\mathrm{u}_{\mathrm{i}}\right)$ is introduced the logit model becomes:

$$
z_{i}=\beta_{0}+\beta_{1} x_{i 1}+\beta_{2} x_{i 2}+\ldots+\beta_{n} x_{i n}+u_{i}
$$

In this study the above econometric model was used to analyze the data. The model was estimated using the iterative maximum likelihood estimation procedure. This estimation procedure yields unbiased, efficient and consistent parameter estimates.

\subsubsection{Parameter estimation}

In order to fit the logistic regression model the estimation of the values of the unknown parameters $\beta_{0}$ and $\beta_{\mathrm{i}}$ 's is required. Unlike the linear regression which uses the least square estimation (OLS) method, this model estimates the parameters using the Maximum Likelihood (ML) method (Gujarati,2003). Due to the non-linearity of the logistic regression model, an iterative algorithm is necessary for parameter estimation. (Gujarati,2003) pointed out that of ML is a very general method of estimation that is applicable to a large variety of problems. The ML method of estimation suggests choosing as estimates the values of the parameters that maximize the likelihood of function (Gujarati, 2003). In many cases, it is convenient to maximize the logarithm of the likelihood function rather than the likelihood function it-self and the same results are obtained.

Before taking the selected variables into the logit model, it is necessary to check for the existence of multicollinerarity among the continuous variables and verify the degree of association among discrete variables. The reason for this is that the existence of multicolliniarity will affect the parameter estimates seriously. The Variance Inflation Factor (VIF) was used to test for the existence of multicollinearity between continuous explanatory variables. VIF shows how the variance of an estimator is inflated by the presence of multicollinearity (Gujarati, 2003). If $\mathrm{R}^{2}$ of the multiple correlation coefficient that results when the explanatory variable, $\mathrm{Xi}$, is regressed against all the other explanatory variables, VIF is computed as follows:

$$
\operatorname{VIF}(\mathbf{X i})=\left(1-\mathbf{R}^{2}\right)^{-1}
$$

As $\mathrm{R}^{2}$ Approaches 1, the VIF approaches infinity. That is as the existence of collinearity increases, the variance of the estimator increases, and in the limit it can become infinity. If there is no collinearity between regressors, the value VIF will be 1 . As a rule of Thumb, Values of VIF greater than 10 is often taken as a signal for the existence of multicollinearity problem in the model (Gujarati, 2003 ). Similarly, there may also be interaction between two qualitative variables, which can lead to the problem of multicollinearity or association. 
To detect this problem, coefficients of contingency were computed from the survey data. Contingency coefficient is a chi-square based measure of association. A value of 0.75 or more indicates a stronger relationship (Healy, 1984). The contingency coefficients are computed as follows:

$$
C=\sqrt{\frac{\chi^{2}}{\chi^{2}+N}} \text { Where } \mathrm{C}=\text { coefficient of contingency } \quad \chi^{2}=\text { chi-square test and } \mathrm{N}=\text { Total sample size }
$$

\section{RESULTS AND DISCUSSION}

\subsection{General characteristics of sample households}

The age structure of the sample households showed that the average of the participant farmers was about 45 years where as that of non-participant was 40 years. As t-test shows there was significant mean difference in average age of the two groups $(\mathrm{t}=2.16, \mathrm{p}=0.023)$ (Table 3$)$.

Table 12. General characteristics of sample households

\begin{tabular}{|c|c|c|c|c|}
\hline \multirow[t]{2}{*}{ Variables } & \multicolumn{2}{|c|}{ Average } & & \multirow[t]{2}{*}{ t-value } \\
\hline & $\begin{array}{l}\text { Participant } \\
=70 \\
\operatorname{Mean}(\mathrm{SD})\end{array}$ & $\begin{array}{l}\text { Non- } \\
\text { participants=48 } \\
\text { Mean(SD) }\end{array}$ & $\begin{array}{l}\text { Total }=118 \\
\text { Mean(SD) }\end{array}$ & \\
\hline Family size & $6(1.9)$ & $4(1.69)$ & $5(1.88)$ & $2.191 * *$ \\
\hline Age of hhs & $45(11.5)$ & $40(10.2)$ & $43(11.2)$ & $2.16^{* *}$ \\
\hline Dependency ratio & $0.88(.32)$ & $0.93(.24)$ & $0.90(.29)$ & $0.94^{* *}$ \\
\hline
\end{tabular}

Source: Survey data, $2017 / 18 * *$ significant at 5 percent level.

\subsection{Characteristics of farm economy}

Land (ha): The average size of cultivated land owned by the sample respondents were about 0.593 hectares, the minimum and maximum being 0.3443 and 0.7581 hectares, respectively. Farmers who participated and nonparticipated in on-farm had almost similar size of average owned cultivated land 0.75 and 0.507 hectares, respectively.

\subsection{Characteristics of non-farm activities}

Non-farm income provides farm households with insurance against the risk of farming and there by enables them to adopt new technologies More importantly, non-farm activities offer cyclical and seasonal employment, to supplement meager farm incomes in many drought-prone areas of Ethiopia. As the survey results depicted, the total sample households 32 percent reported that the non-farm income accounted for the highest proportion of the annual household income but 43 percent of the sample respondents reported that agriculture accounted for the highest share but the reaming 25 percent had got almost equal portion of annual house hold income from both the non-farm and farm activities.

Table 13. Proportion Of annual household income from different sources

\begin{tabular}{|c|c|c|c|c|c|c|}
\hline \multirow[t]{2}{*}{ Income of the households } & \multicolumn{2}{|c|}{ Participant(=70) } & \multicolumn{2}{|c|}{ Non participant $(=48)$} & \multicolumn{2}{|c|}{ Total $=118$} \\
\hline & $\mathbf{N}$ & $\%$ & $\mathbf{N}$ & $\%$ & $\mathbf{N}$ & $\%$ \\
\hline Agriculture takes highest proportion & 35 & 50 & 16 & 33 & 1 & 43 \\
\hline Non-farm takes highest & 20 & 29 & 18 & 38 & 38 & 32 \\
\hline $\begin{array}{l}\text { Both agriculture and non-farm activity } \\
\text { are equal }\end{array}$ & 15 & 21 & 14 & 29 & 29 & 25 \\
\hline Total & 70 & 100 & 48 & 100 & 97 & 100 \\
\hline
\end{tabular}

Source: Survey data, 2017/18; ** significant at 5 percent level.

The distribution of income from non-farm activities shows 52 percent earning the range from less 500 birr to 1500 . This figure dropped to 22 percent earns in the range of less than 500 birr and 17 percent for 500 to 1000 birr income groups. Those farmers earning above 1000 birr were only 13 percent. 
Table 14. Distribution of non-farm income

\begin{tabular}{lllllll}
\hline Income Range & Participant $=\mathbf{7 0}$ & $\mathbf{\%}$ & Non participant $=\mathbf{4 8}$ & $\mathbf{\%}$ & Total $=\mathbf{1 1 8}$ & $\mathbf{\%}$ \\
\hline$<500$ birr & 18 & 26 & 8 & 17 & 26 & 22 \\
$500-1000$ & 12 & 17 & 8 & 17 & 20 & 17 \\
$1001-1500$ & 12 & 17 & 4 & 8 & 16 & 13 \\
$1501-2000$ & 0 & 0 & 0 & 0 & 0 & 0 \\
$>2001$ & 0 & 0 & 0 & & 0 & \\
\hline Total & 42 & & 20 & & & \\
\hline Mean income=69.13 & & & & &
\end{tabular}

Source: Survey data, 2017/18; *** significant at 1 percent level.

\subsubsection{Trade}

Trade in the study area was not only bound with in the woreda locality but also buying and selling was made also other places out of the study area. Traded items like cereals, coffee and livestock were bought on market day and were sold on the same or another market day or at another place. Commercial activities were an important source of income for farmers in the study area.

Food crops were bought from surplus peasant associations in or outside the woreda and sold in deficit areas.. Although trade is a supplementary activity most farmers got satisfactory profits. Among the sample non-farm participant farmers $17,12.5,33$ and 37.5 percent got little, satisfactory and outstanding profit, respectively.

Table 15. Performance of trade

\begin{tabular}{lllllll}
\hline Performance & Participant $=\mathbf{7 0}$ & $\mathbf{\%}$ & Non participant $=\mathbf{4 8}$ & $\mathbf{\%}$ & Total $=\mathbf{1 1 8}$ & $\mathbf{\%}$ \\
\hline Outstanding profit & 40 & 57 & 18 & 37.5 & 58 & 49 \\
Satisfactory & 13 & 18.5 & 16 & 33 & 29 & 25 \\
Little profit & 4 & 6 & 6 & 12.5 & 10 & 8 \\
No profit & 13 & 18.5 & 8 & 17 & 21 & 18 \\
Total & 70 & 100 & 48 & 100 & 118 & 100
\end{tabular}

Source: Survey data, 2017/18

Trade as a source of income for the farmers was hindered by certain constraints. According to farmers, the main constraint for trade in the study area is lack of startup capital. About 24 respondents or 20 percents from those engaged in the non-farm activities said lack of capital was the main challenge. Lack of skills and lack of pack animals and access to market were also mentioned as the bottlenecks for trade activity

Table 16. Constraints associated with trade

\begin{tabular}{lllllll}
\hline Problems & $\begin{array}{l}\text { Participant } \\
=\mathbf{7 0}\end{array}$ & $\mathbf{\%}$ & $\begin{array}{l}\text { Non-participant } \\
\mathbf{= 4 8}\end{array}$ & $\mathbf{\%}$ & Total=118 & $\mathbf{\%}$ \\
\hline Lack of initial capital & 35 & 50 & 24 & 50 & 59 & 50 \\
Lack of pack animal & 12 & 17 & 5 & 10 & 17 & 14 \\
Lack of skills & 14 & 20 & 16 & 33 & 30 & 25 \\
Lack of access of credit & 9 & 13 & 3 & 7 & 12 & 11 \\
Total & 70 & 100 & 48 & 100 & 118 & 10 \\
\hline
\end{tabular}

Source: Survey data, 2017/18

The survey results show that 40 percent of the households participating in non-farm activity were engaged in trade. The mean annual income from trade was about 678.70-birr with a minimum and a maximum of 100 birr and 2350 birr, respectively. About 8 households (17 percent) earned income from trade less than 500 birr. But 60 percent of the non-farm households earned income from trade ranging from 500 to 1000 birr and 10 percent of the non-farm households earned income from trade ranging from 1001 to 1500 birr and 10 percent of the non-farm households earned income from trade ranging from 1501 to 2000 birr respectively. While the rest 3 percent earn more than 2000 birr from trade. The dominant forms of trade items include cash crop trade, grain trade, cattle trade, fruits, vegetable and animal bi-product. In transporting trade items transportation animals such horses, mules and donkey play an important role. Besides, this self-carried, hired vehicles and hired labor were used (Table 22). 
Table 17. Income from Trade activity

\begin{tabular}{|c|c|c|c|c|c|c|}
\hline \multirow{2}{*}{$\begin{array}{l}\text { Income } \\
\text { range }\end{array}$} & \multicolumn{2}{|c|}{ Participant $=70$} & \multicolumn{2}{|c|}{ Non- participant $=48$} & \multicolumn{2}{|c|}{ Total $=118$} \\
\hline & $\mathrm{N}$ & $\%$ & $\mathrm{~N}$ & $\%$ & $\mathrm{~N}$ & $\%$ \\
\hline$<500$ birr & 13 & 18.5 & 8 & 17 & 21 & 18 \\
\hline $500-1000$ & 27 & 38.5 & 29 & 60 & 56 & 47 \\
\hline $1001-1500$ & 23 & 33 & 5 & 10 & 28 & 24 \\
\hline $1501-2000$ & 6 & 9 & 5 & 10 & 11 & 9 \\
\hline$>2001$ & 1 & 1 & 1 & 3 & 2 & 2 \\
\hline Total & 70 & 100 & 48 & 100 & 118 & 100 \\
\hline \multicolumn{7}{|c|}{ Mean income $=678.70$ birr } \\
\hline \multicolumn{7}{|c|}{ Minimum=100 birr } \\
\hline
\end{tabular}

Source: Survey data, 2017/18; * significant at 10 percent level.

\subsubsection{Handicraft activities}

There are a number of crafting activities in which farmers can potentially participate in the study area. Among the non-farm participant farmers 23.7 percent were engaged in crafting activities. These include blacksmiths, weaving, tannery, pottery, carpet making and carpentry. Craft workers produce carpet, clothes, iron-tips, knives, simple chisels, axes, water and cooking pots for the community. The number of households participating in blacksmithing, weaving, tannery thorn (arata) making from skin for sitting purpose , pottery and carpentry 23, 8, 18, 7and 8 respectively (Table 23). As the respondents engaged in handicrafts reported, 64 house holds participating in handicrafties and 54 percent out of 118 household participated on this activities .

Table 18. Engagement in and type of handicraft activities

\begin{tabular}{|c|c|c|c|c|c|c|}
\hline \multirow[t]{2}{*}{ Engagement in and type of handicraft activities } & \multicolumn{2}{|c|}{ Participant } & \multicolumn{2}{|l|}{ Non-participant } & \multicolumn{2}{|c|}{ Total } \\
\hline & $\mathrm{N}$ & $\%$ & $\mathrm{~N}$ & $\%$ & $\mathrm{~N}$ & $\%$ \\
\hline \multicolumn{7}{|l|}{ Households engaged in handicraft: } \\
\hline yes & 36 & 51 & 28 & 58 & 64 & 54 \\
\hline No & 34 & 49 & 20 & 42 & 54 & 46 \\
\hline \multicolumn{7}{|l|}{ Handicraft activity } \\
\hline Blacksmithing & 23 & 33 & 19 & 40 & 42 & 36 \\
\hline Weaving & 12 & 17 & 3 & 6 & 15 & 13 \\
\hline Tannery making Thorn (arata) & 23 & 33 & 10 & 21 & 33 & 27 \\
\hline Pottery & 6 & 9 & 7 & 15 & 13 & 11 \\
\hline Carpentry & 6 & 8 & 9 & 18 & 15 & 13 \\
\hline Total & 70 & 100 & 48 & 100 & 118 & 100 \\
\hline $\begin{array}{l}\chi^{2} \\
=221.315\end{array}$ & & & & & & \\
\hline
\end{tabular}

Source: Survey data, 2017/18;** significant at 5 percent level.

The mean annual household income from handicraft activities was $358.733 \mathrm{birr}$, the highest and the minimum income reported by the being 1800 birr and 140 birr respectively (Table 24)

Table 19. Income from handicraft activity

\begin{tabular}{lllllll}
\hline Income range & $\begin{array}{l}\text { Participated } \\
\text { =70 }\end{array}$ & $\mathbf{\%}$ & $\begin{array}{l}\text { Non-participated } \\
\mathbf{= 4 8}\end{array}$ & $\mathbf{\%}$ & $\begin{array}{l}\text { Total non-farm income } \\
\mathbf{1 1 8}\end{array}$ & $\mathbf{\%}$ \\
\hline$<500$ birr & 22 & 31 & 16 & 33 & 38 & 32 \\
$500-1000$ & 22 & 31 & 12 & 25 & 34 & 29 \\
$1001-1500$ & 16 & 23 & 12 & 25 & 28 & 24 \\
$1501-2000$ & 10 & 15 & 8 & 17 & 18 & 15 \\
$>2001$ & 0 & 0 & 0 & 0 & 0 & 0 \\
Total & 70 & 100 & 48 & 100 & 118 & 100 \\
\hline $\begin{array}{l}\text { Mean income }=376 \\
\text { Maximum }=1800\end{array}$ & & & & & \\
Minimum $=40$ & $\mathrm{t}==2565.9 \mathrm{P}=0.536$ & & & & \\
\hline
\end{tabular}

Source: Survey data, 2017/18;*** significant at 1 percent level.

Farmers reported a number of problems associated with handicraft activities. These were lack of startup capital, lack of pack animals, lack of skill and lack of credit (absence of cooperatives) and negative perception of the community about the hand crafts. Lack of capital and markets were reported by most farmers (Table 25).

As the respondents engaged in the handicrafties reported, they learnt the skill of the work from family, neighbors or friends and training/ education. 
Table 20. Constraints associated with handcraft

\begin{tabular}{lllllll}
\hline problems & $\begin{array}{l}\text { Participant } \\
\mathbf{7 0}\end{array}$ & $\mathbf{\%}$ & $\begin{array}{l}\text { Non participant } \\
=\mathbf{4 8}\end{array}$ & $\mathbf{\%}$ & Total=118 & $\mathbf{\%}$ \\
\hline Lack of initial capital & 31 & 44 & 7 & 15 & 38 & 33 \\
Lack of pack animal & 15 & 21 & 17 & 35 & 32 & 27 \\
Lack of skills & 10 & 15 & 7 & 15 & 17 & 14 \\
Lack of access of credit & 10 & 15 & 4 & 8 & 14 & 12 \\
Negative perception of community & 4 & 5 & 13 & 27 & 17 & 14 \\
\hline Total & 70 & 100 & 48 & 100 & 118 & 100 \\
\hline$\chi^{\mathbf{2}=176.690^{\text {a }} \mathrm{P}=0.174}$ & & & & &
\end{tabular}

Source: Survey data, 2017/18

4.3.4 Sale of food and local drinks

Sale of food and local drinks is mostly practiced in most villages of study area. About40 percent of those who participated in non-farm activities were engaged in sale of food and local drinks. When compared with other nonfarm activities, females dominated in the sale of food and drinks than males. The mean family members engaged in this sector were 3 with minimum of 1 and a maximum of 4 out of 48 participant farmers engaged in this nonfarm activity.

The mean annual income reported from the sale of food and local drinks was 162 birr with a minimum of 140and a maximum of 2500 birr. Among the sample respondents who participated in the sale of food and drinks, 25 percent had got an income greater than 2001 birr but the rest75 percent had got less than 2001birr (Table27).

Table 21. The Income Range from sale food and drinks

\begin{tabular}{lllllll}
\hline Income range & Participant $=\mathbf{7 0}$ & \multicolumn{2}{c}{ Non-participant=48 } & \multicolumn{2}{c}{ Total $=\mathbf{1 1 8}$} \\
& $\mathrm{N}$ & $\mathbf{\%}$ & $\mathrm{N}$ & $\mathbf{\%}$ & $\mathrm{N}$ & $\mathbf{\%}$ \\
\hline$<500$ birr & 0 & 0 & 0 & 0 & 0 & 0 \\
$500-1000$ & 10 & 14 & 19 & 40 & 29 & 25 \\
$1001-1500$ & 10 & 14 & 10 & 20 & 20 & 16 \\
$1501-2000$ & 40 & 58 & 0 & 0 & 40 & 34 \\
$>2001$ & 10 & 14 & 19 & 40 & 29 & 25 \\
\hline Total & 70 & 100 & 48 & 100 & 118 & 100 \\
\hline
\end{tabular}

Mean income $=161.69$

Maximum $=2500$

Minimum $=0.00$

$\mathrm{t}=328.675 \quad \mathrm{P}=0.000$

Source: Survey data, 2017/18; ** significant at-5 percent level.

The major problems reported by the respondents in respect of this activity included lack of initial capital to undertake the activity and lack of market for the produce. Group discussion with the farmers revealed that most of them were engaged in the sale of food and local drinks to supplement the agricultural income. Among the sample respondents no farmers was found engaged in this non-farm activity as major source of livelihood to the family. The respondents under take this activity integrating it with the farm activity.

\subsection{Determinants of farmers' to participation in non-farm activities}

The logit model was used to analyze the determinants of farmer's to participate in non-farm activities. The farm households either participate or not participating in non-farm activities. Consequently, the variable to show participation in non-farm activity was used as a binary dependent variable, taking a value 1 indicating the farmer is participating at least in non-farm activities and 0 other wise. Fourteen explanatory variables (9 continuous and 5 dummy) were included in the model.

Table 29 shows the signs, magnitude and statistical significance of the estimated parameters and how much the observed values were correctly predicted by the logistic regression model. 
Table 22. Variables in the Equation

\begin{tabular}{lllll}
\hline Variables & Coefficients & St. Error & Odd Ratio & Significant level \\
\hline DEPRATIO & -2.077 & 1.714 & 0.125 & 0.226 \\
AGE & -.025 & 0.012 & 0.976 & $0.050^{*}$ \\
FAMILY & -.108 & 0.226 & 0.898 & 0.633 \\
MRSTT & -.880 & .899 & 0.415 & 0.328 \\
SEX & -0.395 & 1.994 & 0.673 & 0.843 \\
EDU & 0.185 & 0.810 & 0.831 & 0.819 \\
TLU & -0.255 & 0.248 & 0.775 & 0.305 \\
LAND & 3.089 & 1.305 & 21.959 & $0.018^{* *}$ \\
CREDIT & 1.824 & 0.818 & 6.197 & $0.026^{* *}$ \\
TRAIN & 1.262 & 0.472 & 0.283 & $0.002^{* * *}$ \\
& & & & \\
EXTN & -.180 & 0.163 & 0.835 & 0.268 \\
INPUT(1) & -5.230 & 0.952 & 0.005 & $0.000^{* * *}$ \\
OXEN & 0.570 & 0.438 & 1.769 & 0.193 \\
MKSTI & -0.058 & 0.134 & 0.944 & 0.664 \\
CONSTANT & 9.555 & 4.494 & 14111.265 & $0.034^{* *}$ \\
\hline
\end{tabular}

Chi-square $=90.012 * * *$

Correctly predicted on non-farm $=85.4$

Correctly predicted farm participant $=90.0$

Over all correctly predicted $=\quad 88.1$

-2Loglikelihood $=69.44$

Cox and Snell $\mathrm{R}^{2}=0.634$

Nagelkere $R^{2}=\quad 79.00$

Source: Survey data $2017 / 18 ; * * *, * *, *$ significant at $1 \%, 5 \%$ and $10 \%$ probability level.

The likelihood ratio test statistic exceeds the Chi-square critical value with 13 degree of freedom. The result is significant at less than 1 percent probability level indicating that the hypothesis that all the coefficients except the intercept are equal to zero is rejected. The goodness of fit of the model was found to be 1 percent. And the log likelihood was 69.44. Another measure of goodness of fit used in logistic regression analysis is the count $\mathrm{R}^{2}$ which indicates the number of sample observations correctly predicted by the model. The count $\mathrm{R}^{2}$ is based on the principle that if the estimated probability of the event is less than 0.5 , the event will not occur and if it is greater than 0.5 the event will occur (Gujarati, 2004). In other words, the $i^{\text {th }}$ observation is grouped as participant if the computed probability is greater than or equal to 0.5 , and as a non-participants otherwise. The model results show that the logistic regression model correctly predicted 88.1 percent of the sample households. The sensitivity (correctly predicted non-farm participant) and the specificity (correctly predicted non-participant) of the logit model are 85.4 and 90 percent, respectively. Thus, the model predicts both groups accurately (Table 29).

In this study, fourteen explanatory variables were used. Out of the fourteen proposed variables, five of them were statistically significant in the model while the rest were not significant at less than ten percent probability level. The interpretations of the significant explanatory variables are given below:

Age of the household (AGE): This variable is significant at 10 percent probability level and negatively associated with the participation in non-farm activities. The sign shows that as the age of the household increases, the probability to be non-participant in non-farm activity increases. All other things being kept constant, the odds ratio in favor of showing interest to participation in non-farm activities decreases by a factor of 0.976 as the age of the household head increased by one unit. Hence the younger households have to rely on non-farm employment to support their livelihood. A study conducted by Destaw (2003) and Berhanu (2007) have also presented similar result.

Credit service (CREDIT): This variable has a positive correlation with participation in nonfarm activities at 5 percent probability level. The result shows the variable is a positive impact on the probability of participating in non-farm activity in the study area. The odds ratio in favor of participation in non-farm activities increases by a factor of 6.197 for farmers who have credit service. This is because making awareness for credit use (liquidity) enables the household to finance purchase of equipment's, skills acquire, capital for initial investment and purchase of inputs. The study conducted by (Bezu and holden,2008) supports the finding of this study.

Use of Inputs (INPUT): This variable has a positive correlation with participation in nonfarm activities at less than 1 percent probability level. The result shows the variable is a positive impact on the probability of participating in non-farm activity in the study area. The odds ratio in favor of participation in non-farm activities increases by a factor of 0.005 for farmers who have access to input. This refers Farmers with higher non-farm earnings were more risk taking as was evident in their higher level of input usage. Non-farm earnings thus had a positive sign for input usage. The study conducted by (Tassew., 2000) supports the finding of this study. 
Cultivated Land (LAND) This variable has a positive correlation with participation in nonfarm activities at less than 5 percent probability level. The result shows the variable is a positive impact on the probability of participating in non-farm activity in the study area. The odds ratio in favor of participation in non-farm activities increases by a factor of 21.959 for farmers who have access to land. Cultivated land is assumed to influence nonfarm activity positively. This means access to land that encourages farmers to participate in non-farm activity, increases non-farm income. This is because farmers with cultivate more land diversified income may tend to undertake various production decisions such as sharecropping, land-renting, etc. The study conducted by (Davis,J.R, 2003) Supports the finding of this study.

Entrepreneurship Training (TRAIN): This variable is significant at 1 percent probability level and positively associated with the participation in non-farm activities. All other things being kept constant, the odds ratio in favor of showing interest to participation in non-farm activities decreases by a factor of 0.283 as the training on entrepreneurship of the household head increased by one unit. A positive association between training on entrepreneurship and non-farm employment was empirically established. Better trained individuals possess skills which facilitate successful involvement in non-farm activities. For Żmija (2001) entrepreneurial development in rural areas has been connected with a progressive modernization of agriculture and is connected with multifunctional rural development.

\section{SUMMARY, CONCLUSIONS AND RECOMMENDATION}

\subsection{Summary and Conclusions}

In countries like Ethiopia, where the subsistence agriculture and the small holder farming dominates the overall National Economy, small holder farmers often face scarcity of capital and are prone to livelihood risk. This problem can be solved through increasing agricultural productivity and non-farm income there by improving the ability of households to stabilize their income and food purchasing power.

The principal objective of this study was to identify and analyze the determinants of farmers' participation in non-farm activities and also intended to describe the characteristics of the non-farm and farming activities of the area.The data used for the study were collected from 118 households drawn from Humbo woreda farming system. A multi-stage sampling was used to select households. In the first stage, six kebeles were randomly selected out of the 41 found in the woreda. Taking a list of households in the selected kebeles, which was obtained from the kebele offices, the households in each kebeles were classified in to non-farm activity practitioners and nonpractitioners. In the second stage, simple random sampling based on probability proportional to size was used to select respondents from each household category. In addition, secondary data were extracted from relevant sources to supplement the data obtained from the survey.

Regarding the determinants of participation in non-farm activity, fourteen variables hypothesized to explain farmer's participation in non-farm activities were used to estimate the logit model. The results of the binomial logit model revealed that two variables were significant at 1 per cent probability level; two variables were significant at 5 percent probability level ;one was significant at 10 per cent probability level while nine other variables were insignificant. Age of household was significant at less than 10 per cent probability level. Entrepreneurship training and input was significant at 1 per cent probability level. Credit and land use was significant at 5 per cent probability level. In this study, the conclusion and policy recommendations were given based only on those variables, which were significant.

For the determinants of non-farm activity, distance to market was negatively related with participation in nonfarm activities. The variable land had positive and significant influence on participation in nonfarm activities. This is access to land increase farm income to support their livelihood compared to landless. This is because, younger farm households cannot get enough land to support their livelihood compared to the older farm households. Therefore the younger households have to rely more on non-farm employment than the older ones to support their livelihood. The variable education also had a positive and significant influence on participation in non-farm activities. Non-farm activities require some skill and training hence households with some skills and education tend to engage in non-farm activities. The other important variable that influences the non-farm activities participation is access to credit. This variable positively correlated with the dependent variable. This is because the presence of credit enables the household to finance purchase of equipment, skill acquisition, capital for initial investment and purchase of inputs.

Understanding the determinants of non-farm activities and the characteristics of the farm and non-farm activities would help policy makers to design and implement more effective policies and programs for non-farm enterprises and there by helps to pave way for the increase in agricultural production. In this respect, this study provides a base and point of departure for similar studies in the future.

Based on the findings of the study, the following points need to be considered as possible policy implications in order to increase agricultural production and enhance productive participation in non-farm activities. 


\subsection{Recommendation}

- The results show that farmers engaged in non-farm activities earn diversify income and lessen risks from farming. The fact that non-farm income is positively related with agricultural income and those farmers with higher non-farm income is better-off than those with low non-farm income. Therefore the rural development strategy should not only emphasis in increasing agricultural production but concomitant attention should be given in promoting non-farm activities in the rural areas.

- The findings of the study revealed that farmers who trained on entrepreneurship are more likely to involve in non-farm activities. Thus entrepreneurship training could be an effective instrument in increasing participation in non-farm activities. Therefore the task of upgrading the skills and production techniques of local farmers should be given a special attention. Development programs to promote non-agricultural employment should focus on strengthening of existing skill development centers at local level.

- Credit is a key input in every development program; this is particularly true for rural development because so long as sufficient credit is not provided to the development programs of poor sections of the society, the goal of development cannot be achieved. This holds true particularly for the progress of non-farm activities in the study area. As the study results show, farmers who have credit service increasingly participate in nonfarm activities. This is because credit removes the financial constraint and enables them to finance the initial capital of the nonfarm sector. Therefore, the rural policy would do well to provide better service to credit for the rural people by motivating micro-finance institutions.

\section{REFERENCE}

Abbott, P. 2013. The Role of Non-farm Household Enterprises in Poverty Reduction, Employment Creation and Economic Growth in Rwanda. Rwanda Agricultural Economics, 35, 449-458. Agricultural Sustainability, 2 , 133-146.

Andersen, D \& Leiserso, M. W. (1980) Rural Non-farm Employment in Developing Countries. Economic Development and cultural change, 28, 227-248.

Barret, C. B., Reardon, T. \& Webb, P. (2001) Nonfarm income diversification and household livelihood strategies in rural Africa: concepts, dynamics, and policy implications. Food policy, 26, 315-331.

Bezu, S. \& Holden, S. (2008) Can food-for-work encourage agricultural production? Food policy, 33, 541-549.

Block, S. \& Webb, P. (2001) The dynamics of livelihood diversification in post-famine.

Central Statistical Authority (CSA). 1990. Statistical Abstract. . 1993. Report on cropland utilization: Agricultural sample survey, 1988/89. Statistical Bulletin, no. 11. .1995 . Report on cropland utilization: Agricultural sample survey, 1989/90. Statistical Bulletin, no. 129.Change 34, no. 2: 299-314.

Choices and Constraints Journal of Development Studies, 32, 850-875.

CSA \& WB (2008). The 2006/2007 Rural Investment Climate Survey: Basic Information Document. Addis Ababa: processed.

CSA (1998) Report on the 1995/1996 household income, consumption and expenditure survey.

CSA (2001) Report on the 1999/2000 household income, consumption and expenditure survey.

CSA (2007) Household Income, Consumption \& Expenditure (HICE) Survey 2004/5: Analytical Report. Statistical Bulletin. Central Statistical Agency of Ethiopia.

CSA (2007) Household Income, Consumption and Expenditure (HICE) Survey 2004/5:

CSA(Central Statistical Authority), 2009. Population Estimates. Ethiopia, Addis Ababa.

CSA (2009). National Strategy for the Development of Statistics. Addis Ababa.

CSA (Central Statistics Agency), (2008) 'Summary and Statistical report of the 2007 population and housing census', Addis Ababa, Ethiopia.

Davis, J. R., 2003. Rural Non-Farm Economy: Livelihoods and their Diversification, Issues and Options. NRI Report No. 2753.

Destaw Berhanu, 2003. Non-farm Employment and Farm Production of small holder Farmers: A Study in Edja District of Ethiopia.

Ellis, F. \& Biggs, S. (2001) Evolving Themes in Rural Development 1950s-2000s. Development policy review, $19,437-448$.

Ellis, F. (2000) rural livelihoods and diversity in developing countries, Oxford, Oxford University Press.

FAO, 2009. Proceeding from the Forum on Operationalzing Sustainable Livelihoods Approaches. ODI, Uk, London.

Federal Democratic Republic of Ethiopia.Ministry of Agriculture Rural Development. Draft Final Report; 2010. Food Pol., 26(4): 315-331.

Gujarati, D.N., 2003. Basic Econometrics, 3th ed. McGraw-Hill, USA.

Haggblade S, Hazell P, Reardon T (2010). The rural non- farm economy: prospects for growth and poverty.

H.R.Sharma, (2006). Non-farm employment growth. Growth in rural non-farm employment to inter linkages between demand and supply. 
Janvry, A. \& Sadoulet, E. (2001) Income strategies among rural households in Mexico: The role of off-farm activities. World Development, 29, 467-480.

Johnston, B. F. \& Kilby, P. (1975) Agriculture and structural transformation: Economic strategies in latedeveloping countries, Oxford University Press New York.

Lanjouw, P. \& Shariff, A. (2002) Rural Non-farm Employment in India: Access, Income and Poverty Impact. Working Paper series No.81.

Loening, J., Rijkers, B. \& Soderbom, M. (2008) Nonfarm microenterprise performance and the investment climate: evidence from rural Ethiopia.

Lofgren, H. \& Robinson, S. (1999). To Trade or Not to Trade: Non-Separable Farm Household Models in Partial and General Equilibrium. IFPRI, TMD Discussion Paper, 37. Washington, D.C.

Matsumoto, T., Kijima, Y. \& Yamano, T. (2006) the role of local nonfarm activities and migration in reducing poverty: evidence from Ethiopia, Kenya, and Uganda. Agricultural economics, 35, 449-458.

Ministry of Labor and Social Affairs, 1997.Agricultural Wage Employment and Rural Non-farmEmployment in Ethiopia.Survey Results. Addis Ababa, Ethiopia.

Prasada Rao Machar (2002). Determinants of Rural non-farm employment in two villages of Andhra pradese India.

Reardon, T. (1997) Using evidence of household income diversification to inform study of the rural nonfarm labor market in Africa. World Development, 25, 735-747.

Reardon, T., Berdague, J., \& Escobar, G. (2001) Rural Nonfarm employment and Incomes in Latin America: Overview and Policy Implications. World development 29, 395-409.

Reardon, T., Berdegué, J., Barrett, C. B. \& Stamoulis, K. (2007) Household income diversification into rural nonfarm activities. Transforming the Rural Nonfarm Economy. Opportunities and Threats in the Developing World. Johns Hopkins University Press, Baltimore.

Reardon, Thomas, Julio Berdegué, Christopher B. Barret and Kostas Stamoulis (2007), "Household Income Diversification into Rural Nonfarm Activities," Transforming the Rural Nonfarm Economy.Opportunities and Threats in the Developing World, S. Haggblade, P. Hazell and T. Reardon, Eds., Baltimore and London, The John Hopkins University Press.

Ruben, R \& Van Den Berg, M. (2001) Nonfarm Employment and Poverty Alleviation of Rural Farm Households in Honduras. World development 29, 549-560.

Shylendra, H. \& Thomas, P. 1995. Non-Farm Employment: nature, magnitude and determinants in a semi-arid village of Western India. Indian Journal of Agricultural Economics, 50, 410-416. Sharad Rajian (2009). Occupational diversification and acces to rural employment. Non-farm employment Debate, 2009, India.

Tassew Woldehanna .2000. Economic Analysis and Policy Implications of Farm and Off-Farm Employment.Mansholt Institute, Wageningen, The Netherlands.

Tefera, T. L., Perret, S. \& Kirsten, J. F. (2005) Diversity in Livelihoods and Farmers Strategies in the Hararghe Hilands, Eastern Ethiopia. International Journal of Agricultural Sustainability, 2, 133-146.

TegeneGebregziabher .1996. Impact and Determinants of Non-farm Activities: the case of Damota gale and KachaberaWoreda in Southern Regions of Ethiopia. Organization for Social Science Research in Eastern and Southern Ethiopia. Addis Ababa. Ethiopia.

Tekle and Berhanu, 2015 Determinants of Rural Farm Household Food Security in Boloso Sore District of Wolaita Zone in Ethiopia 2015; Asian Journal of Agricultural Extension, Economics \& Sociology 5(2): 57-68, 2015; ISSN: 2320-7027.

Tewdros Girma and Van dea Beag (2012). Farm assets and non-farm activities Characterstics and determinants of non farm activities in Small holder farmers: The case of North East Ethiopia, Tehuedere Disrict. Master Thesis Submitted to Management, Economics and Consumer studies, Wagenigen University. Netherlands. 72 page.

Van Den Berg, M. \& Kumbi, G.E. (2006) Poverty and The Rural nonfarm economy in Oromia, Ethiopia. Agricultural Economics 35, no, supplement 3, 469-475

Wiggins, S. \& Hazell, P. (2011) Access to rural non-farm employment and enterprise development. Background Paper for the IFAD Rural Poverty Report. 51

Winters, P., Davids, B., Carletto, G., Covarrubias, K., Quinones, E. J., Zezza, A., Azzarri, C. \& Stamoulis, K. (2009) Assets, Activities and Rural Income Generation: Evidence from a Multicounty Analysis. World Development, 37, 1435-1452.

Woldehanna, T (2000) Economic Analysis and Policy Implications of Farm and Off-Farm Employment. A Case Study in the Tigray Region of Northern Ethiopia. PhD thesis. Wageningen: Wageningen University, the Netherlands.

World Bank. Ethiopia Country Brief, the World Bank Group. Washington DC: The World Bank; 2012

Yamane T., 1967. Statistics:An Introductory Analysis, $2^{\text {nd }}$ ed. Harper and Row, New York . 